\title{
Access to Land and Food Security: Analysis of 'Priority Crops' Production in Ogun State, Nigeria
}

\author{
Ngozi Adeleye ${ }^{\mathrm{a}}$, Evans Osabuohien $\mathrm{a}, \mathrm{e}, \mathrm{f}$, Samuel Adeogun ${ }^{\mathrm{b}}$, \\ Siraj Fashola ${ }^{\mathrm{b}}$, Oyinkan Tasie ${ }^{\mathrm{c}}$, Gideon Adeyemid
}

${ }^{a}$ Dept. of Economics \& Development Studies, Covenant University, Nigeria;

bPlanning, Research and Statistics, Ogun State Ministry of Agriculture, Nigeria;

${ }^{c}$ Dept. of Agriculture, Food \& Resource Economics, Michigan State University, USA

${ }^{\mathrm{d}}$ Geographic Info. System (GIS) Centre, Dept. of Civil Engineering, Covenant University, Nigeria

${ }^{\mathrm{e}}$ Alexander von Humboldt Visiting Professor, Witten/Herdecke University, Witten, Germany

${ }^{\mathrm{f}}$ Chair, Centre for Economic Policy and Development Research (CEPDeR), Covenant University, Nigeria

[Correspondence: ngozi.adeleye@,covenantuniversity.edu.ng]

Final Version is Published as:

Adeleye, N., Osabuohien, E., Adeogun, S., Fashola, S., Tasie, O. \& Adeyemi, G. (2020). Access to Land and Food Security: Analysis of 'Priority Crops' Production in Ogun State, Nigeria. In, Osabuohien. E (Ed.) The Palgrave Handbook of Agricultural and Rural Development in Africa (pp. 291-311). Cham-Switzerland: Palgrave Macmillan. DOI: https://doi.org/10.1007/978-3-030-41513-6 14.

\begin{abstract}
Using Ogun State located in south-western Nigeria, this chapter draws attention to the increase in output productivity of priority crops in the State from 2003 to 2015 due to the acquisitions of over 47,334 hectares of agricultural land across 28 communities in different Local Government Areas (LGAs). From Ogun State Agriculture Data, eight priority crops are analyzed: cassava, maize, rice, melon, yam, cocoyam, potato and cowpea. Statistics reveal that the cultivation of cassava gives the highest average output of 4,515,620 metric tonnes and yield per hectare of 16.41 relative to other produce which affirms that Ogun State has the most comparative advantage in the cultivation of cassava followed by maize. The chapter further explores other pro-poor programmes directed at ensuring food security in the State.
\end{abstract}

Keywords: land access; land use; land policy; food security; crop production; priority crops; ecological clustering; agriculture, land security; pastoralists; farmers; cassava; hectarage; yield; Ogun State; agricultural policy; arable land; land ownership; food research; agro-food; maize; rice; melon; yam; cocoyam; cowpea; potato 


\section{Nigeria's Land Use Policy and Agro-Food Agenda: An Overview}

Agriculture is conventionally considered as the 'backbone' of Nigeria's economy with many assigned roles to perform in the course of achieving economic advancement. Among the roles are: the provision of adequate food for the growing population; providing sufficient raw materials to its budding manufacturing sector; constituting the main source of employment; creating a major source of foreign exchange earnings; and providing a market for the products of the industrial sector. However, problems in the agricultural sector began to arise about a decade after independence with increasing food supply short-falls, rising food prices and declining foreign exchange earnings from agricultural exports, rising food import bills, and declining labour force required in the sector. The situation was further worsened by the aftereffects of the civil war, severe droughts in some parts of the country, government fiscal and monetary policies and above all, an 'oil boom' which created serious distortions in the economy and accelerated the rate of migration of labour from agriculture.

To stem this declining tide, the federal government embarked on several agriculture promotion schemes required to revamp the sector amongst which is the move from rudimentary farming (small-scale) to commercialized farming in the form of large-scale land investments (Osabuohien, 2014; Osabuohien, et al, 2019) and a renewed vigour into research, innovation and development (Federal Ministry of Agriculture, 2016). Therefore, it is correct to say that Nigeria is using research into the agricultural sector to drive its food security agenda as obtained in developed countries. For instance, research institutions in developed economies have played extremely important roles by undertaking basic research required to support the strategic goals of promoting food security in their respective countries. They transfer these ideas through the use of adaptive and applied research using various international centres, forums to provide the necessary training for other developing-country researchers (Reeves, Pinstrup-Andersen, \& Pandya-Lorch, 1998; Hajirostamlo, Mirsaeedghazi, Arefnia, Shariati, \& Fard, 2015).

Furthermore, agro-food research in Nigeria is recognized as a critical enabler of economic growth. It is therefore prioritized by the constitution and explicitly assigned as the primary responsibility of the federal government on the concurrent legislative list. Thus, the importance of agro-food research in driving the country's overall food agenda towards national food security, import substitution and job creation cannot be overemphasized. To this end, concerned stakeholders, institutions and bodies at different locations in the country are required to conduct research for increased agricultural productivity and to make the research outcomes available to farmers and other actors in the agricultural development of the states. Finally, to boost Nigeria's commercialization drive and achieve one of its agenda for Vision 2020, the need for agro-food research is thus summarized herein.

First, investment in agro-food research must be accelerated if the country is to assure future food security for its citizens at reasonable prices and without irreversible degradation of the natural resource base. This is needful as the country will not achieve reasonable economic growth, poverty alleviation, and improvements in food security without productivity increases in agriculture. Also, agro-food research will enable yield-enhancing technology for the majority of crops grown in the country. The production of foundation seeds or improved crop varieties and their subsequent multiplication as commercial seeds; the development of hybrids with less than optimal production conditions reduces risks and uncertainty and enhances sustainability in production through better management of natural resources and reduced environmental risks. In addition, it will lead to the development of risk-averse measures resulting in tolerance or resistance to adverse production factors such as pests and drought, leading to biological and integrated pest control. 
In addition, agro-food research will help to ensure sustainability. The international agricultural research centres have recognized the importance and urgency of research to assure sustainability in agricultural intensification through appropriate management of natural resources (CGIAR, 2005)i. In the same vein, accelerated research will prevent land degradation and reduce pressures on fragile lands across the geo-political zones with particular attention to addressing extensive waterlogging and other forms of land degradation. Lastly, since a large proportion of Nigeria's population reside in the rural areas - characterized by low-incomes and poverty, incentives should be provided to the private sector to undertake biotechnology research using modern science with focus on the problems of local farmers which will assist in reducing poverty in the local communities. Failure to expand agricultural research significantly will make food security, poverty, and environmental goals elusive.

In the same vein, since ensuring food security is one of the main challenges of the 21 st century in developing countries, the knowledge of land use and the formulation of policies governing its usage is important not just in an agrarian economy like Nigeria, but applies to other developing regions globally, due of its natural connection of land with diverse aspects of human lives (Issa, Nei, Wellyngton, Gabriel, Franciani Rodrigues, Haendchen, Mihaela, Baltazar, \& Andrade, 2019). Likewise, the efficiency of any food security is a function of an effective land management system because land policy determines the frameworks for land ownership and development in any society (Kuma, 2017).

Land policy is a significant tool in the determination of rights, protection, and transfer of wealth in addition to ensuring food security. Land policy development is very important in a society in order to ensure a condition of orderliness and a legal framework upon which transfer, acquisition and uses will take place without certain vices and/or anti-cultural dispositions and conflicts. The formulation of a land policy involves a complex and dynamic process that is influenced by different factors, such as political constraints, rent-seekers etc. However, there is the dichotomy among scholars, jurists and stakeholders as to where land ownership lies. Does ownership lie with the State or with individual citizens? The system of land ownership requires a critical review in Nigeria as this will enhance agricultural productivity and promote the mechanized farming that is needed to prevent hunger, ensure food security and prevent poverty. In Nigeria like most African countries, it is generally accepted that land is the property of the family with the community as a corporate unit. Hence, land is the property of both the living, the dead and the unborn members of the families and community by virtue of its transferability from generation to generation (Kingston \& Oke-Chinda, 2016). To achieve Nigeria's agro-food agenda, Akintunde (2015) argues that land should be available for those that are ready to farm and not for speculators.

This study positions on Ogun State and gives a depiction of the synergy between land access and food security for several reasons: (1) it is one of the six states in the South-West geopolitical zones of Nigeria with arable land of 1,204,000ha and cultivated area of 350,000ha; (2) it is strategically positioned given its agricultural and location advantages to becoming an agricultural powerhouse; (3) proximity to Lagos State and Economic Community of West African States (ECOWAS) markets like Cotonou and Idiroko border towns create growing demand for its food products and a competitive advantage for export and logistics, and (4) the State is endowed with fertile arable land and significant rainfall for two planting seasons in a year and available water bodies for all year round irrigated farming. Therefore, stemming from the above, this chapter explores the nexus between access to land and food security in Ogun State focussing on the production of crops deemed to be priority. The remainder of the study is structured as follows: Section 2 discusses Ogun State's food policy agenda; Section 3 details the ecological zoning of crops, Section 4 examines pattern of hectarage and output of priority 
crops; Section 5 discusses impact of farmers-herders conflicts on the food security agenda while Section 6 concludes with some policy recommendations.

\section{Ogun State Food Policy Agenda}

Ogun State is one of the 36 States in Nigeria, predominantly a yoruba-speaking State was created on $3^{\text {rd }}$ of January 1976 with an approximate population of 5.2 million people

2. It is located in South-West geopolitical zone and borders Lagos State to the south, Oyo and Osun States to the north, Ondo State to the east and the Republic of Benin to the west. Abeokuta is the capital and the largest city in the State (Osabuohien, Osabohien, \& Okorie, 2018). With respects to agriculture in Ogun State, statistics reveal that about 3 million people live in the rural area which is the mainstay of agricultural engagements. The number of farming households is probably above 360,000 persons, which comprises an average family size of 4.8 persons. Recently, the State acquired over 47,334 ha of agricultural land across 28 communities in different Local Government Areas (LGAs) that are deemed to be suitable for the cultivation of crops such as cassava, rice, cocoa, maize, plantain and oil palm. The State has a blend of agrarian (Ijebu Ode, Sagamu, Ijebu Igbo, Ilaro, Ayetoro) and industrial (Abeokuta and Ota) communities.

The total land area is $1,685,100$ hectarage with total arable land estimated to be $1,204,000$ representing $71.45 \%$ of total land area (see Table A1 in Appendix). Out of the above total arable land, about 350,000 hectares is presently cultivated, which constitutes 29.07 percent of arable land area. The general vegetation cover comprises: rain forest, swamp forest and derived savannah (Ogun State Government, 2016). As at 2015, the State had allocated over 31,000ha $(32.6 \%)$ to various agricultural investors implying that there still exist about $67.4 \%$ of un-used agricultural land sites. The State intends to create clusters of production and value addition, around selected crops and specially targeting increased participation of youth and women. In addition, it will provide enablers around improving access to land and security, roads, inputs, capacity building, among others. Given the above fallouts, this study carries out an empirical investigation of enhanced crop production focusing on the priority crops in Ogun State, Nigeria. This is achieved using survey data collected by the Ogun State Agricultural Development Programme in various LGAs, which was analysed using quantitative techniques.

According to Dada (2017), the land use pattern in Ogun State is described as majorly arable, permanent pastures, permanent crops, forest and a host of others. Thus, land ownership is still the main asset of the people. However, for the farmers, this asset has not been put to optimal use, partly due to lack of proper registration and titles acceptable for use as collateral to raise capital as well as ascertain ownership. Given that the abilities of both small-landholders and commercial-scale farmers to own arable land (land access) is a pre-cursor to ensuring agroproduce, the Ogun State Government (OSG) put in place several measures towards ensuring that the farmers' agricultural cycle is not threatened. Some of the measures are: (1) that there are secure dealings on land matters, (2) transaction costs are kept low, (3) farmers have credit access, (4) land dealings are transparent, (5) no discrimination on land participations, (6) protection of minority rights, especially women and (7) environmental sustainability is supported. From the Ogun State Ministry of Agriculture, it takes an average of 3 to 6 months for an individual to secure land for agricultural purposes (which can be through leasing or borrowing) while it takes an average of 7 months for a corporate body (commercial scale) to obtain the same. Successful individual applicants are entitled to a maximum of 19 hectares of land while that for a corporate body is not specific ${ }^{3}$.

In order to ensure that agriculture in the State is focused on increasing the productivity of smallholder's farmers in a sustainable manner that is market driven, the State Government established the Ogun State Agricultural Development Programme (OGADEP, 2017) to provide 
the necessary technical back-stopping for farmers in areas of crops, livestock and fisheries through relevant capacity building along the value chain. This is essential as the role of value chain development in enhancing agricultural production cannot be overemphasized (Oyebola, Osabuohien \& Obasaju, 2019). On gender participation, the State Government and other nongovernmental Organizations (NGOs) recognize the roles played by women in agricultural production and local processing. The current issue in rural women development is now tending towards, recognizing the possible ways of sustaining all developmental programmes aimed at improving the lives of rural women. Generally, in Nigeria, a number of gender-specific developmental projects like Better Life Programme for Rural Women (BLPRW), Women-InAgriculture (WIA), the Family Support Programme (FSP), have been introduced to take care of women's needs in the rural areas (Adisa \& Okunade, 2005).

In Ogun State, the Women-in-Agriculture (WIA), a component of OGADEP Extension Structure is providing technical support to women in form of training to enhance the utilization of major food crop and at the same time influence their nutrition status. For instance, the women are trained in the processing of cassava into chips, floured starch and its utilization for confectioneries; yam processing into chips and flour and the tuber and flour utilization for porridge etc.; plantain processing into flour and chips; maize processing into paste and flour, fortification and utilization as weaning diet; fortification and enhancement of carbohydrate food with soya bean amongst others (OGADEP, 2017). All these measure are to support the food security initiative of the State Government. Specifically, the cassava value chain in Ogun State is a major employer of labour with virtually every household in the rural and semi - urban communities producing one cassava-based product or another plus the cassava processing small and medium scale enterprises (SMEs) engaging between 15 to 25 direct employees each not to mention the indirect employment associated with haulage/carriage of the raw tubers from the farm to the vehicle location, loading and offloading of the vehicles, vehicle hire/transportation, ad - hoc staff, supplier of water for processing. Cassava plays a major role in the livelihoods of women, youth, transporters, and other players in Nigeria. About $90 \%$ of cassava farmers are smallholders with 95\% women responsible for the processing and marketing of cassava (Sanni, Siwoku, \& Adebowale, 2012; Adeogun, Adeleye, Fashola, \& Osabuohien, 2017) .

\section{$3 \quad$ Ecological Clustering in Ogun State}

To ensure food security, Ogun State is divided into four ecological zones identified as best suited for the production of certain crops and livestock, in terms of soil properties, relative humidity, rainfall levels, vegetative cover, temperature fluctuations and day length. The zones are: the guinea savannah area; rain forest area; mid-region of the rain forest area; and fresh water swampy area. The guinea savannah area comprises Egbado North, part of Egbado South and Abeokuta Local Government Areas (LGAs), which is suitable for the production of cassava, maize, melon, cowpea, yams, soyabeans, citrus and cocoa. The rain forest area is made up of Odeda, Remo, part of Ijebu-East, Ijebu-Ode, and Ijebu-North LGAs that is reputed for the production of maize, plantain, cassava, kola, cocoa, oil palm, citrus, cowpea, and rubber. The mid-region of the rain forest area is made up of Obafemi/Owode and Ifo/Ota LGAs suitable for the production of rice, maize, cassava, and cowpea. The fresh water swampy area entails mainly Ijebu East, which is well suited for fish and swamp rice production (Awotide, 2012; Adeogun et al., 2017).

The map of Ogun State highlighting the ecological zones vis-à-vis the crops produced are depicted in Figure 1, while details on ecological clustering including population density per hectarage as well as major crops produced are presented in Table A1 in the Appendix. 


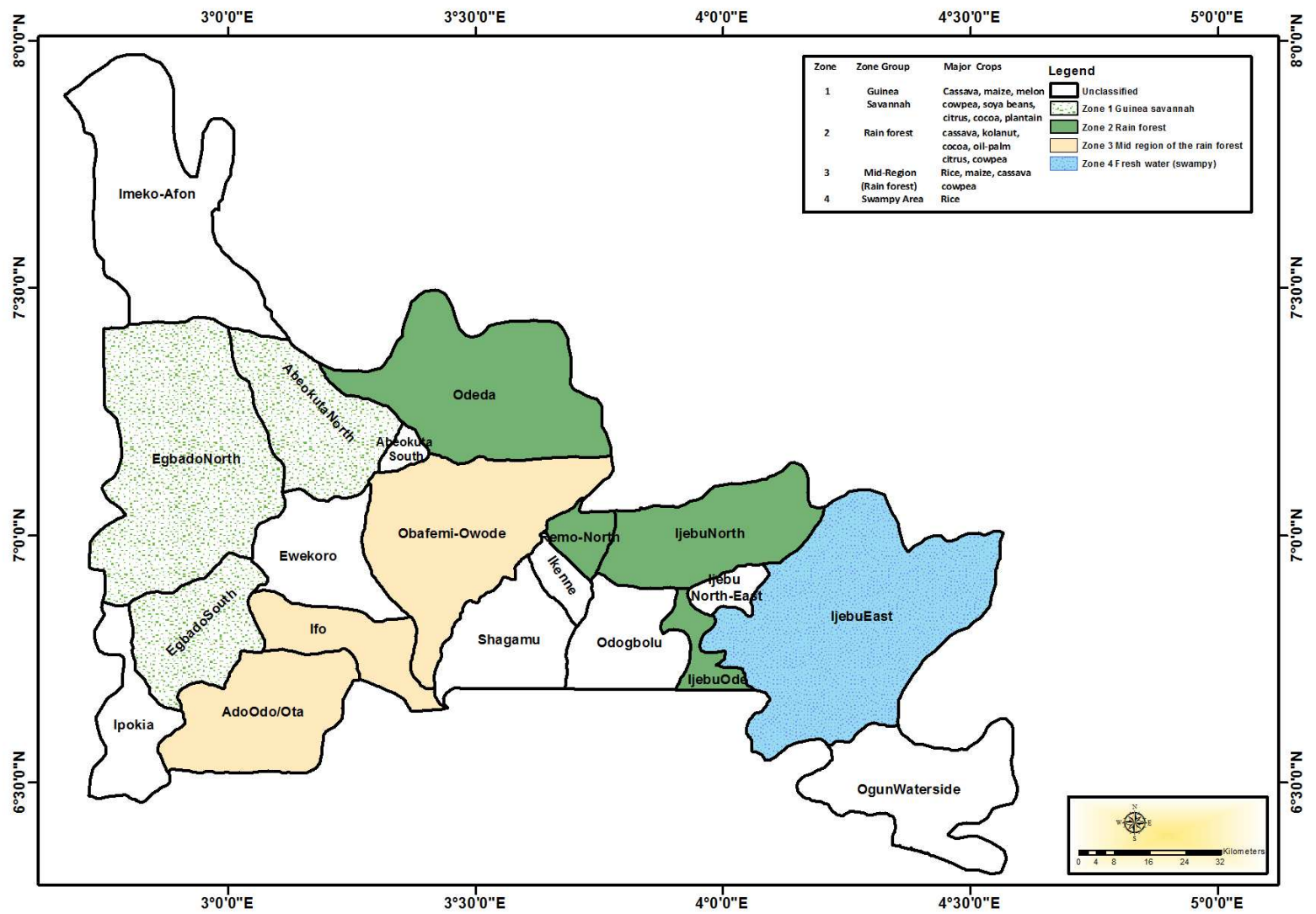

Figure 1: Ecological clustering of crops in Ogun State Source: The Authors'

\section{Land Access and Food Production of Priority Crops in Ogun State}

The data utilised for the descriptive analysis is obtained from the annual surveys conducted by Ogun State Agricultural Development Programme (OGADEP) in the major Local Government Areas (LGAS) where the crops are grown across the State. We build the empirical analyses of the crops that are known as the priority crops due to the volume of production, acreage of cultivation as well as potential for commercial values in the State (Ogun State GovernmentOSG, 2016). The period covered using the State-level data is from 2003 to 2015, which is the survey period covered by OGADEP. The crops listed according to cultivation acreage and output quantity include: cassava, maize, rice, yam, cocoyam, potato, cowpea, and melon. Table 1 shows the average harvested area, output and yield of each crop. 


\begin{tabular}{llccl}
\hline Table 1 & $\begin{array}{l}\text { Average Values of the Crops } \\
\text { Cultivated Land }\end{array}$ & $\begin{array}{l}\text { Output Produced } \\
\text { (Metric Tonnes) }\end{array}$ & $\begin{array}{l}\text { Yield per } \\
\text { Hectare }\end{array}$ \\
\hline S/n & Crop & (Hectares) & $4,515,615.10$ & 16.408 \\
\hline 1 & Cassava & $270,829.00$ & $316,235.23$ & 1.3323 \\
3 & Maize & $233,672.38$ & $32,256.00$ & 1.249 \\
4 & Rice & $25,156.10$ & $14,041.10$ & 0.628 \\
5 & Melon & $21,171.10$ & $182,620.30$ & 8.684 \\
6 & Yam & $20,711.60$ & $51,831.20$ & 5.744 \\
7 & Potato & $19,331.00$ & $82,360.80$ & 6.013 \\
8 & Cocoyam & $18,279.60$ & $2,241.20$ & 0.725 \\
\hline
\end{tabular}

Note: The crops are arranged according to size of land cultivated

Source: The Authors'

Statistics reveal that cassava is cultivated on a larger farm area of 270, 829 hectares with 4.5 million metric tonnes produced on the average giving a yield of 16.41. Following cassava are maize, yam, cocoyam, potato, rice, melon and cowpea, in that order. The study advanced further by examining the performance of the above crops over the years given the various interventionists programmes of Ogun State Government.

\subsection{Hectarage, Output and Yield Pattern of Priority Crops}

Using descriptive statistics, this section examines the pattern of land cultivated, output produced and yield of five out of the eight priority crops ${ }^{4}$. Statistics in Tables 2 details the pattern of these crops using comparative year-bands approach to show if there is an improvement in a measure compared to the previous band which to some extent shows the impact of the State Government's interventionist's policies towards ensuring food security in the State. Each crop is analyzed in turn.

Table 2 Hectarage, Output and Yield Pattern of Priority Crops (2003 - 2015)

\begin{tabular}{|c|c|c|c|c|}
\hline Measures & Crops & $2003-2007$ & $2008-2015$ & \% Change \\
\hline \multirow{5}{*}{$\begin{array}{l}\text { Cultivated Land } \\
\text { (Hectares) }\end{array}$} & Cassava & 230,365 & 296,119 & 28.54 \\
\hline & Maize & 200,825 & 254,202 & 26.58 \\
\hline & Rice & $11,251.80$ & $67,894.75$ & 503.41 \\
\hline & Yam & $14,769.20$ & 26,654 & 80.47 \\
\hline & Melon & 16,219 & $26,123.20$ & 61.07 \\
\hline & All Crops & $94,686.00$ & $153,223.90$ & 61.82 \\
\hline \multirow{6}{*}{$\begin{array}{l}\text { Output Produced } \\
\text { (Metric Tonnes, } \\
\text { '000) }\end{array}$} & Cassava & $3,594.58$ & $5,091.26$ & 41.64 \\
\hline & Maize & 272.14 & 343.79 & 26.33 \\
\hline & Rice & 13.53 & 90.33 & 567.63 \\
\hline & Yam & 121.41 & 243.83 & 100.83 \\
\hline & Melon & 8.38 & 19.70 & 135.08 \\
\hline & All Crops & 802.00 & $1,338.85$ & 66.94 \\
\hline \multirow{6}{*}{ Yield per Hectare } & Cassava & 15.48 & 16.99 & 9.75 \\
\hline & Maize & 1.37 & 1.31 & $(4.38)$ \\
\hline & Rice & 1.19 & 1.29 & 8.40 \\
\hline & Yam & 8.26 & 9.11 & 10.29 \\
\hline & Melon & 0.49 & 0.76 & 55.10 \\
\hline & All Crops & 5.36 & 6.06 & 13.06 \\
\hline
\end{tabular}


Note: Percentage change is computed as: [((period 2008 to 2015) - (period 2003 to 2007)/((period 2003 to 2007) ) $\times 100$ ]; Yield is computed as: Metric Tonnes/Hectares; data for Yam and Melon ends at 2012

Source: Authors' Computations from Ogun State Agriculture Data

\subsubsection{Cassava}

Cassava is generally considered the predominant crop in the state by area of hectarage against other crops cultivated in the State. The crop is grown in the guinea savannah area (made up of Egbado North, part of Egbado South, and Abeokuta local government areas), rain forest area (comprising Odeda, Remo, part of Ijebu-East, Ijebu-Ode and Ijebu-North local government areas) and mid-region of the rain forest area (Obafemi/Owode and Ifo/Ota local government areas). A report of the Food and Agriculture Organization (FAO $)^{5}$ gives a brief expose on the relevance of cassava both a staple delicacy and as a source of raw materials for industrial production. Cassava is a very versatile commodity with numerous uses and by-products. Each component of the plant is valuable to its cultivator. The leaves are consumed as vegetables, cooked as a soup ingredient, dried and fed to livestock as a protein feed supplement. The stem is used for plant propagation and grafting. The roots are typically processed for human and industrial consumption.

In Ogun State, just as in other parts of the country, garri, a roasted granule is the dominant product and is widely accepted in both rural and urban areas. It can be consumed without any additives or it can be consumed with a variety of additives such as sugar, groundnut, fish, meat and stew. The fermented wet paste, locally called $f u f u$ is widely-consumed throughout the southern zones. It is known as akpu in the South-Eastern and South-Southern regions. On its industrial usage, estimates from the FAO suggest that approximately 16 percent of cassava root production is utilized as an industrial raw material in 2001 in Nigeria. Ten percent used as chips in animal feeds, 5 percent processed into a syrup concentrate for soft drinks and less than one percent processed into high quality cassava flour used in biscuits and confectionary, dextrin pre-gelled starch for adhesives, starch and hydrolysates for pharmaceuticals, and seasonings (Kormawa \& Akoroda, 2003). This estimate leaves 84 percent or 28.9 million tonnes of production for food consumption, a portion of this of course being lost in post-harvest and waste.

Nevertheless, cassava plays a major role in the livelihoods of women, youth, transporters, and other players in Nigeria. About $90 \%$ of cassava farmers are smallholders with $95 \%$ women responsible for the processing and marketing of cassava (Sanni et al, 2012). Cassava processing has moved from cottage/ small and medium scale enterprises (SMEs) to large scale with most of these large scale companies situated in Ogun State (Adeogun et al, 2017). Over the last 13 years, the output and yield of cassava have consistently improved. A close look at the statistics reveal that between 2003 and 2007, cassava was planted on 230, 365 hectares of land which as a result of more land farming land acquisition by the government, increased to 296,119 hectares representing an increase of $28.54 \%$. The effect of the increase in average land cultivated can be observed from the pattern of output produced which increased on average by $41.64 \%$ from 3.59 million metric tonnes to 5.09 million metric tonnes. As expected, the average yield also grew by $9.75 \%$ from $15.48 \%$ to $16.99 \%$. Some of the measures introduced in boosting the production of agriculture in the state are provision of more arable lands for cultivation ${ }^{6}$, use of hybrid cassava seeds which reduces planting and harvesting periods, use of fertilisers, educating farmers on embracing new planting techniques, improved value-added chain that allows off-takers to be available to pick up the products, availability of micro-scale finance and so on. These measures have been successful in ensuring that cassava maintains its status as the State's main priority crop.

\subsubsection{Maize}


This is the commonest grain produced in Ogun state and adjudged to be the second priority crop in terms of hectarage, output and yield. The crop is also grown in the guinea savannah area, rain forest area and mid-region of the rain forest in the State and produced within two seasons, namely, early and late maize. Its major economic importance is hinged on human consumption, livestock feeds and industrial processes including breweries and confectionaries. For the records, the demand for maize is very high within the State and across neighbouring towns and States. Maize is a cereal plant that produces grains that can be cooked, roasted, fried, ground, pounded or crushed to prepare various food delicacies like pap (called ogi), 'tuwo', 'gwate', 'donkunu' and host of others. All these food types are readily available in various parts of Nigeria among different ethnic groups, notably among which are the Yorubas, Hausas, Igbos, Ibiras, Ishas, Binis, Efiks, Yalas, among others. According to Abdurahaman and Kolawole (2006) maize is known and called by different vernacular names depending on locality like 'agbado', 'igbado' or 'yangan' (Yoruba); 'masara' or 'dawar masara' (Hausa); 'ogbado' or 'oka' (Ibo); 'apaapa' (Ibira); 'oka' (Bini and Isha); 'ibokpot' or 'ibokpot union' (Efik) and 'igumapa' (Yala). The maize meal is also used as a replacement for wheat flour, to make cornbread and other baked products.

In addition, since Ogun State has one of the largest concentration of industries in the country, maize has become a source of raw materials for most of the agro-based based industries located in Ota and Agbara industrial areas of the State. It is used most especially in the production of pharmaceutical drugs, ethanol, confectionaries, beverages and other manufactured goods. Hence, the crop maintains its status as the second priority crop and to further boost all the indices of maize production, the State Government is proposing the establishment of additional 7,000 hectares of maize farms ${ }^{7}$. As a result of more allocated farming lands, the cultivation of maize increased on average from 200,825 hectares of land to 254,202 hectares representing an increase of $26.58 \%$ (see Table 2). The impact of more cultivated lands led to an average increase of $26.33 \%$ in productivity from 272,140 metric tonnes to 373,970 metric tonnes. However, this did not transmit to an increase in yield which declined from 1.37 yield per hectare to 1.31 yield per hectare representing a decline of $4.38 \%$. This decline is not unconnected to inadequate rainfall, poor seedlings (non-treated seedlings), old rudimentary ways of farming, poor farming techniques, inadequate fertilisers, pests' (termites, ants, and millipedes) and birds invasion etc.

\subsubsection{Rice}

This is third priority (mandate) crop in terms of area harvested and sixth in terms of output. Like other rice producing states, Ogun state, is the foremost producer of rice in the Southwestern part of the country and is billed to become one of the expected exporters of rice. Indeed, the State is popular for its production of brown rice popularly referred to as Ofada rice. The crop is grown the swampy area of Ijebu East and in the rain forest area of Obafemi/Owode and Ifo/Ota local government areas and according to Osabuohien et al., (2016), eight out of the 20 LGAs in Ogun State, representing 40 percent, are involved in rice production. These LGAs include: Abeokuta North, Egbado North, Ewekoro, Ifo, Ijebu-North, Ikenne, Obafemi Owode, and Ogun Waterside. The produce is predominantly cultivated by rice farmers in the agrarian town of Eegua, in Yewa North Local Government Area of the state who have vowed to make the produce in abundant supply provided they get the required assistance from government at all levels ${ }^{8}$. As expected, these have made Ogun State become a major player in rice sector revolution in Nigeria. Rice possesses both local and industrial values. It can be cooked from its raw form into several local delicacies like "white rice", "jollof rice", "fried rice" "coconut rice" etc. Its blended and fermented form is processed to make "tuwo" which is eaten with different varieties of soups. Industrially, rice oil is processed from the bran for both food and industrial uses. Broken rice is used in brewing, distilling, and in the manufacture of starch 
and rice flour. Hulls are used for fuel, packing material, industrial grinding, fertilizer manufacture, and in the manufacture of an industrial chemical called furfural ${ }^{9}$.

From Table 2, the cultivation and production of rice have consistently witnessed an upswing across all parameters. As a result of the State government's drive to increase rice productivity, the size of land cultivated increased on average from 11,251.80 hectares to 67,874.75 hectares representing 503.41\%. Not surprising, a similar impact is seen on the output which showed an average increase of $567.63 \%$ signalling an increase in output produced from 13,530 metric tonnes to 90,330 metric tonnes. In the same vein, the yield per hectare increased by $8.40 \%$ from 1.19 yield per hectare to 1.29 . It is noteworthy to mention that, the success recorded in the production of rice is directly connected to the initiatives of the incumbent governor who invested in heavy land-clearing equipment in a scale never witnessed in the annals of the state in 2013. Just recently, another investment was made on farm machinery. Hundreds of acres of land have been cultivated. More hectares are being cleared for rice production after the successful launch of MITROS (Mission to Rebuild Ogun State) Rice in December 2018. This marked a positive turning point for Ogun State making it a prime rice-producer in the country ${ }^{10}$.

\subsubsection{Melon}

Melon, known locally as egusi is a type of melon that is very popular in South-western, Eastern Nigeria and other parts of the country. Egusi melon seeds are popular condiments in Nigerian local soups. It resembles small-size water melon with only edible seeds while its flesh is bitter and inedible. The crop is a good source of oil, protein, minerals, vitamins, and energy in form of carbohydrates. This is also one of the priority crops grown in the guinea savannah area of the State. It is predominantly farmed in Egbado North, Egbado South, Abeokuta North, and Abeokuta South Local Government Areas. Due to its domestic and industrial values, the crop benefited from more arable land for planting by the State Government. As a result of more allocated farming lands, the cultivation of melon increased on average from 16,219 hectares of land to 26,123.20 hectares representing an increase of $61.07 \%$ (see Table 2). The effect of more cultivated areas led to an average increase of $135.08 \%$ in productivity from 8.38 metric tonnes to 19.70 metric tonnes translating to an increase in yield per hectare of 0.76 from 0.49 representing a percentage change increase of $55.10 \%$. A cursory look at the data revealed that the crop witnessed a rising trend from 2003 till 2011 from where it experienced a negative shock whose reversal cannot be confirmed due to lack of data. Also, relative to the land area harvested, the trend analysis of the yield curve is on the rise.

\subsubsection{Yam}

Nigeria is adjudged to be the world's largest producer of yams, accounting for over 70-76 percent of the world production ${ }^{11}$. The country produces 18.3 million tonnes of yam from 1.5 million hectares, representing 73.8 percent of total yam production in Africa. Several States in the country contribute to the national production of the crop of which Ogun State is one. The crop is also grown in the guinea savannah area of the State, is the fifth crop in terms of area harvested and third in output and predominantly farmed in Egbado North, Egbado South, Abeokuta North, and Abeokuta South Local Government Areas. Yam has both domestic and industrial uses. The production process of yam is summarized this: yam selection: fresh harvested yam gotten from the farm are sorted to select whole-some tubers that are suitable for the production of instant pounded yam flour; milling: the dried yam slices are milled directly into flour of uniform particle size. Domestically, it can be processed into several forms to make different delicacies such as pounded yam, locally called iyan, yam pottage called asaro, fried yam known as dundu. It can also be roasted. Industrially, it is used in production of all-purpose-adhesives. The adhesives are used by producers of cartons, packaging companies and lather and shoe producers. The all-purpose adhesives is produced with yam or cassava starch. The State Government's pro-poor programmes to stimulate agro-production and ensure food security led more cultivated lands for yam. This increased on average from 
14,769.20 hectares to 26,654 hectares representing an increase of $80.47 \%$ (see Table 2). The outcome of more cultivated areas led to an average increase of $100.83 \%$ in productivity from 121.41 metric tonnes to 243.83 metric tonnes which further translates to an increase in yield per hectare of 9.11 from 8.26 representing a percentage change increase of $10.29 \%$. Yam production has consistently witnessed an upswing from 2003 to date perhaps because yam is a staple meal across all households in the country.

\subsubsection{Other Crops}

Other crops, namely: cocoyam, potato, and cowpea ${ }^{12}$ have also shown relative improvements. Cocoyam is grown in the guinea savannah and cultivated on 18,279.60 hectares of land. Output produced is about 82,360 metric tonnes with 6.013 yield per hectare. Potato is cultivated in the rain forest region of the State on 19,331 hectares of land producing a yield of 5.74 from an output of 51,831.20 metric tonnes. Lastly, cowpea is the least cultivated. It is grown in the midregion of the rain forest on a sparse 2,126.33 hectares of land with an average output of $2,241.20$ metric tonnes and 0.73 yield per hectare.

\subsection{Comparative Advantage}

From the eight crops presented in Table 1, the study further examined those with comparative advantage by matching their respective average area harvested with average output and yield per hectare from 2000-2015 ${ }^{13}$. These statistics are depicted in Figures A1 and A2 of the Appendix. As shown in Figure A1, the cultivation of cassava gives the highest average output of 4,515,620 metric tonnes relative to other produce. Likewise, the crop produced the highest yield per hectare of 16.41 relative to other crops as shown in Figure A2 which confirms that Ogun State has the highest comparative advantage in the cultivation of cassava. The statistics suggest that more returns for food production and processing can be derived from the cultivation of cassava compared to the other seven crops. This is essential as the agricultural transformation processes taking place in the State and the country in general has led to the enhancement of value chains. For instance, there has been an increase in the availability of offtakers, out-grower schemes as well as the emergence of mechanised cassava processing plants in many parts of Nigeria ${ }^{14}$.

\section{Challenges to Ogun State Food Security Agenda}

\subsection{Farmers-Herders Conflicts}

A major challenge to the food security agenda of the State Government is the recurring farmersherders clashes which are mainly attributable to resource control and divergent value systems in the country. The movement of pastoralists from one area of the country to another is usually caused by the increasing demand for fresh grazing grounds (Alawode, 2013; Adelakun, Adurogbangba, \& Akinbile, 2015). From the Focus Group Discussions (FGDs) in Imeko/Afon, Yewa and Ewekoro Local Governments with the representatives of farmers, herders, religious leaders, security apparatus, women society and the youths, the persistent conflicts between farmers and pastoralists has threatened both the food security agenda of the State in addition to the security of lives and properties of the people. Some recent incidences are those recorded in Iwoye-Ketu (located in Imeko/Afon axis) in 2017; Oja-Odan, Igbogila, Owunbe, Egua (in Yewa axis) in 2016; and Afamu, Onigbegu and Kajola (in Ewekoro axis), amongst others. These sporadic invasions of pastoralists on farmlands have led to the abandonment of farms with grave multiplier effects on agro-produce and farmers' living conditions. Information gathered from the FGDs reveal that the conflicts are rampant in dry seasons than in rainy seasons when grazers seeks greener pastures for their herds and in all cases, the pastoralists do encounter problems with the local people because farmers' crops were being destroyed. Evidences reveal the destructive nature of the menace. Across all ecological zones of the State, the cost of these crises is mounting. From loss of farmlands, crops, incomes, livelihoods and 
lives these conflicts have grave multiplier effects on the economy (Adisa, 2012; Adelakun et al., 2015; MercyCorps, 2015).

As a resolution, both the Federal and State Government are working harmoniously to put an end to these menace by proposing grazing reserves, ranching and carving out new stock routes for the herdsmen. For instance, Nigeria has 415 government designated grazing reserves throughout the country, while farmer-herdsmen reconciliatory committees in most conflict prone states have been set up to control resource-based conflicts among farmers and pastoralists (Adisa \& Adekunle, 2010; Adelakun et al., 2015). These proposed measures have been received with mixed reactions from the concerned parties. The farmers oppose grazing but support ranching while the herders oppose ranching while supporting the idea of grazing reserves. The grazing reserve is not wholly supported due to insufficient lands available for crop production while the herders want unrestricted movement for their cattle. A case in point is that in Imeko/Afon, Yewa and Ewekoro the farmers did not support the idea of grazing zones because the farmlands are open areas, unfenced with likely encroachment on farmlands since the herders are not likely to hold up their own end of the agreement ${ }^{15}$. The herdsmen on the other hand, prefer open areas. Overall, the lack of trust between both parties is a huge problem, which has become a major challenge to Ogun State's food security agenda.

\subsection{The Need for Information Technology in Agricultural Productivity}

The earth furnishes the raw materials that we use in our daily lives, either directly in the manufacturing of the goods we consume or in the formation of the soils upon which we depend on for agriculture. (Peters et al., 2010). Land mass arable portion is limited in supply, it is a natural resource that must well be taken care of and its utilization must be well planned. Application of information technology in land management and administration is of significant importance especially in the developing countries where land resources need more digital management. The benefits of integrated remote sensing and Geographic Information Systems (GIS) technique in cadastral mapping and land use zoning cannot be overemphasized. The ability of remote sensing to provide a repetitive look of the earth surface makes it a veritable tool in determining changes over time and space of an area.

Other applications of GIS and remote sensing technologies in agriculture include: pests and disease control, crop yield estimation, afforestation planning, soil suitability mapping, erosion control, wildfire control and myriads of other benefits. This technology is able to bring orderliness to land management and administration, digital copies of land information could be kept for a longer period of time, land ownership and transfers could easily be managed and tracked and land encroachment could easily be monitored. Information technology in land use and monitoring to favour agricultural development would go a long way in enhancing food security in the state In addition, effective land administration would need proper monitoring whereby the potency of laws, codes, ordinances and zoning restrictions must be fully exercised at the federal, state and local government levels. A zoning classification describes the permitted use of the site. This legal description determines the type of development in a location (Daisy, 2006).

\subsection{Other Challenges}

There are other factors that are capable of reducing total productivity in the agrarian sector culminating into adverse shortage of food supply, loss of income to households, loss of revenue to the State and Federal Governments, loss of foreign revenue and rising food prices. For instance, documentary evidence reveals that even with prohibitive lending rates, commercial banks are still averse to lending to farmers (exposure is about 6\%) while the insurance sector's exposure in the sector is less than 3\%, measured by farmers enrolled and cropping area covered (CBN, 2016; Federal Ministry of Agriculture, 2016). The role of financial institutions in the 
commercialization agenda is paramount to driving agro-exports, enhancing tradability, increasing global competitiveness and foreign exchange (Osabuohien \& Olayiwola, 2010; Akinyemi et al, 2019). Also, the allocation of lands from smallholders to large-scale farmers arises the problem of land inequality and in its wake loss of wealth and income inequality of small land farmers (Unal, 2007). In addition, majority of the farmers operate largely in local markets due to lack of connectivity to more lucrative markets at local, national or global levels.

\section{Conclusion and Policy Recommendations}

The study analyzes the land access and food policy initiatives of the Ogun State government in Nigeria from 1980 to 2015. To drive agro-food production, the State Government divided the 20 LGAs across four ecological zones such that the various pro-poor programmes required to stimulate the agricultural sector saw a reversal of the declining trend and a rise began to occur from 2014. The main reason for zoning into different geographical areas according to their resource endowments, is to identify those areas that have a relative advantage in the production of certain crops and livestock, as well as other non-farm products, over other areas, with a view to maximally utilising the areas for the production of the crops/livestock so identified, at the best economic levels. Also, the study shows that to ensure food security, the State is involved in the production of several crops of which eight (cassava, maize, rice, melon, yam, potato, cocoyam and cowpea) of them are highlighted and given available statistics. Evidence reveals that Ogun State has comparative advantage in the cultivation of cassava in the areas of cultivated land area, productivity and yield relative to others.

Given the above, in order to ensure food sustainability for the people, the study recommends that:

1. There is the need for the State Government to have a long term agricultural development plan (e.g. between 20 and 25 years) to ensure consistency and continuity of agricultural policies;

2. The Ogun State should reduce its over-dependence on cassava produce while establishing its comparative advantages on related crops such as yam, potato, cocoyam, and rice;.

3. A comprehensive agricultural land database with information on cultivated land, ratio of women and youth participations vis-à-vis ratio of small - commercial land owners is necessary for planning;

4. Visible presence of the State Government on acquired lands is needed and where there are infractions, the necessary institutions should enforce the law, which will make the land acquisition processes to be less cumbersome and more transparent;

5. Delineation of agricultural land after a comprehensive land mapping of the State and ensure that such land is used for agricultural purposes and not to succumb to pressure to release it for other purposes; and

6. Work out a lasting solution to the persistent farmers-herders clashes in the State.

In conclusion, the desire of the Ogun State Government to become an agricultural powerhouse with the capacity not to only feed her residents but supply farm produce outside the State using the platform of crop production can be realised when the needed supports are accorded as enumerated above. This will also involve the private sector engagements that will provide complementary roles through up-takers and out-grower schemes. This is essential as the farmers will have the needed farm inputs as wells as the assurance that there are ready-markets for farm produce which adds value to their labour. As suggestions for future studies, and given data availability, the cost of farmers-pastoralists conflicts on food security in Ogun State using both descriptive and econometrics analysis may be taken up. 


\section{References}

Abdurahaman, A. A., and Kolawole, O. M. (2006). Traditional Preparations and Uses of Maize in Nigeria. Ethnobotanical Leaflets, 10, 219-227.

Adelakun, O. E., Adurogbangba, B., and Akinbile, L. A. (2015). Socioeconomic Effects of FarmerPastoralist Conflict on Agricultural Extension Service Delivery in Oyo State, Nigeria. Journal of Agricultural Extension, 19(2), 1-12. doi:10.4314/jae.v19i2.5

Adeogun, S., Adeleye, N., Fashola, S., and Osabuohien, E. (2017). Promoting Cassava Productivity in Ogun State: Linking Data and Policy. Nigeria Agricultural Policy Project (Feed the Future). State Policy Note 6.

Adisa, B. O., and Okunade, A. (2005). Assessment of Rural Youth Participation in Community based Rural development Projects in Osun State, Nigeria. Internal Journal of Biological and Physical Sciences, 10(1), 18-25.

Adisa, R. S. (2012). Land Use Conflict Between Farmers and Herdsmen - Implications for Agricultural and Rural Development in Nigeria: In Tech.

Adisa, R. S., and Adekunle, O. A. (2010). Farmer-Herdsmen Conflicts: A Factor Analysis of Socioeconomic Conflict Variables among Arable Crop Farmers in North Central Nigeria. Journal of Human Ecology, 30(1), 1-9.

Akintunde, K. O. (2015). The Land Use Act and Land Ownership Debate in Nigeria: Resolving the Impasse.

Akinyemi, O., Efobi, U., Asongu, S., \& Osabuohien, E. (2019). Renewable energy, trade performance and the conditional role of finance and institutional capacity in sub-Sahara African Countries. Energy Policy, 132 , 490-498.

Alawode, O. O. (2013). Determinants of Land Use Conflicts Among Farmers in Southwestern Nigeria. Journal Research in Peace, Gender and Development, 3(4), 58-67.

Awotide, D. O. (2012). Assessment of Women's Participation in Cooperative Societies and its Determinants in Yewa North Local Government Area of Ogun State, Nigeria. Asian Journal of Agriculture and Rural Development, 2(3), 344-350.

CBN. (2016). Central Bank of Nigeria Communiqué No. 105 of the Monetary Policy Committee Meeting of Monday and Tuesday, January 25 and 26, 2016. Abuja: Central Bank of Nigeria.

CGIAR. (2005). Science for Agric Development. Retrieved from www.cgiar.org/enews/december2005/scienceforagrdev.pdf, Rome, Italy:

Dada, S. (2017). Public-Private Dialogue Report on Land Administration, Registration and Acquisition in Ogun State. Nigeria: Deutsche Gesellschaft für Internationale Zusammenarbeit (GIZ).

Daisy, L.K. (2006), Land Development $10^{\text {th }}$ edition

Federal Ministry of Agriculture. (2016). The Agricultural Promotion Policy (2016 - 2020). Abuja: Federal Government of Nigeria.

Hajirostamlo, B., Mirsaeedghazi, N., Arefnia, M., Shariati, M. A., and Fard, E. A. (2015). The Role of Research and Development in Agriculture and Its Dependent Concepts in Agriculture. Asian Journal of Applied Science and Engineering, 4(10), 79-83.

Issa, I. B., Nei, A. N., Wellyngton, S. A., Gabriel, A. A., Franciani Rodrigues, S. V., Haendchen, F., Mihaela, S. J., Baltazar, S. O., and Andrade, G. (2019). The Contributions of Public Policies for 
Strengthening Family Farming and Increasing Food Security: The Case of Brazil. Land Use Policy, 82, $573-584$.

Kingston, K. G., and Oke-Chinda, M. (2016). The Nigerian Land Use Act: A Curse or a Blessing to the Anglican Church and the Ikwerre Ethnic People of Rivers State. AJLC, 6(1), 147-158.

Kormawa, P., and Akoroda, M. O. (2003). Cassava Supply Chain Arrangements for Industrial Utilization in Nigeria. Ibadan: IITA.

Kuma, S. S. (2017). Land Policy and Land Delivery System in Nigeria: Emerging Issues in Urban Land Use and Development.

MercyCorps. (2015). The Economic Costs of Conflicts and the Benefits of Peace: Effects of FarmerPastorist Conflict in Nigeria's Middle Belt on State, Sector and National Economies. Retrieved from https://www.mercycorps.org/.../Mercy\%20Corps\%20Nigeria\%20Household\%20Costs, Portland, Oregon:

Ogun State Agricultural Development Programme (OGADEP) (2017). Work/Plan Budget 2017. Paper presented at the 30th Refils Workshop on OXFAR/EXTENSION Proposals Year 2017, Institute of Agricultural Research and Training, Near Gate House, Ibadan (April 25-28, 2017).

Ogun State Government. (2016). Ogun State - Nigeria Investors' Forum. Retrieved from Retrieved 30th June 2016, from http://ogunstateinvestorsforum.ng/agriculture/.

Osabuohien, E., and Olayiwola, W. (2010). Enhancing Tradability of SSA's Agricutural Exports: What can Institutions Offer?, 1-25.

Osabuohien, E. S. (2014). Large-scale Agricultural Land Investments and Local Institutions in Africa: The Nigerian Case. Land Use Policy, 39(July), 155-165. doi:10.1016/j.landusepol.2014.02.019

Osabuohien, E. S., Osabohien, R., and Okorie, U. (2018). Rice Production and Processing in Ogun State, Nigeria: Qualitative Insights from Farmers' Association. In Obayelu, E. (Eds). Food Systems Sustainability and Environmental Policies in Modern Economics (pp. 188-216), Hershey, PA: IGI Global. DOI: 10.4018/978-1-5225-3631-4.ch009).

Osabuohien, E., Efobi U.R., Herrmann R. \& Gitau, C.M. (2019). Female Labor Outcomes and Largescale Agricultural Land Investments: Macro-Micro Evidence from Tanzania. Land Use Policy, 82, 716728.

Oyebola, P. O., Osabuohien, E. \& Obasaju, B. (2019). Employment and Income Effects of Nigeria's Agricultural Transformation Agenda. African Journal of Economic and Management Studies. DOI: https://doi.org/10.1108/AJEMS-12-2018-0402.

Peters, S.W, Ekpo I.J., Bisong, F.E (2010) Environmental Education (Module 1) for Nigerian Conservation Foundation

Reeves, T., Pinstrup-Andersen, P., and Pandya-Lorch, R. (1998). Food Security and the Role of Agricultural Research. Resource Management in Challenged Environments, 97-102.

Sanni, L. O., Siwoku, B. O., and Adebowale, A. A. (2012). Baseline Survey Report of Cassava ValueChain in Ogun State.

Unal, F. G. (2007). The Impact of Land Ownership Inequality on Rural Factor Markets. Policy Innovations. 


\section{Appendix}

Table A1 Ecological Clustering of Crop Production

\begin{tabular}{|c|c|c|c|c|c|c|}
\hline S/No. & Ecological Zones & LGAs & Population & $\begin{array}{c}\text { Area } \\
\text { (Hecterage) }\end{array}$ & Density & Major Crops \\
\hline 1 & Guinea Savannah & 6 & $1,034,924$ & 587,900 & 0.568 & $\begin{array}{l}\text { Cassava, maize, melon, } \\
\text { cowpea, yams, soya } \\
\text { beans, citrus, cocoa }\end{array}$ \\
\hline 2 & Rain Forest & 9 & $1,284,828$ & 656,900 & 0.511 & $\begin{array}{l}\text { Maize, plantain, cassava, } \\
\text { kolanut, coca, oil-palm, } \\
\text { citrus, cowpea }\end{array}$ \\
\hline 3 & $\begin{array}{l}\text { Mid-Region } \\
\text { (Rain Forest) }\end{array}$ & 4 & $1,335,409$ & 340,300 & 0.254 & $\begin{array}{l}\text { Rice, maize, cassava, } \\
\text { cowpea }\end{array}$ \\
\hline \multirow[t]{2}{*}{4} & Swampy Area & 1 & 72,935 & 100,000 & 1.371 & Rice \\
\hline & Total & 20 & $3,728,096$ & $1,685,100$ & 2.705 & \\
\hline
\end{tabular}

Notes: LGAs: Local Government Areas; Density: Area/Population; Guinea Savannah: Egbado North, Egbado South, Abeokuta North, Abeokuta South; Rain Forest: Odeda, Ijebu East (part), Ijebu Ode, Ijebu North; MidRegion (Rain Forest): Obafemi/Owode, Ifo, Ado-Odo Otta; Swampy Area: Ijebu East (part), Ogun Waterside Source: The Authors'

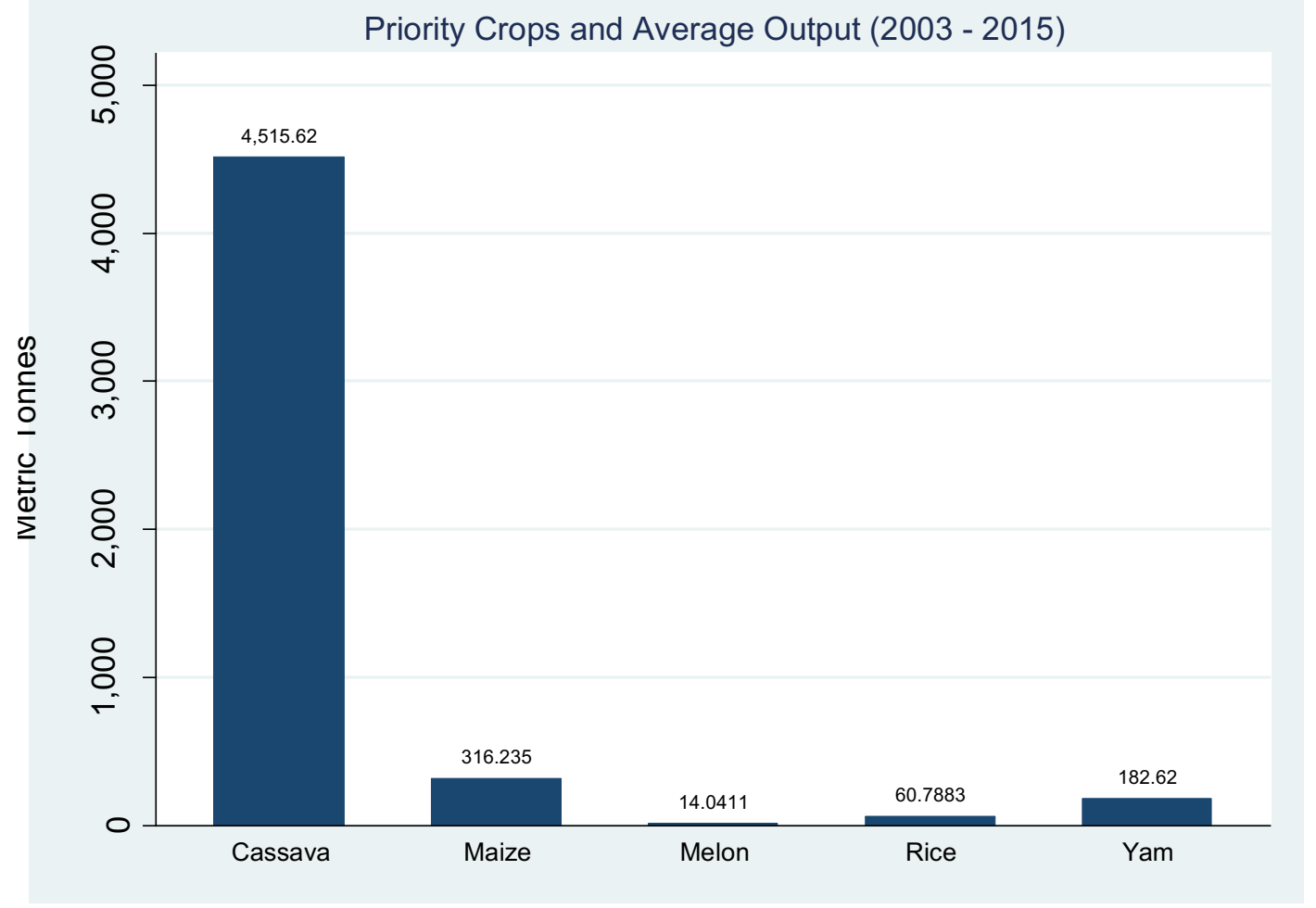

Figure A1: Output of selected priority crops in Ogun State, Nigeria Source: The Authors' 


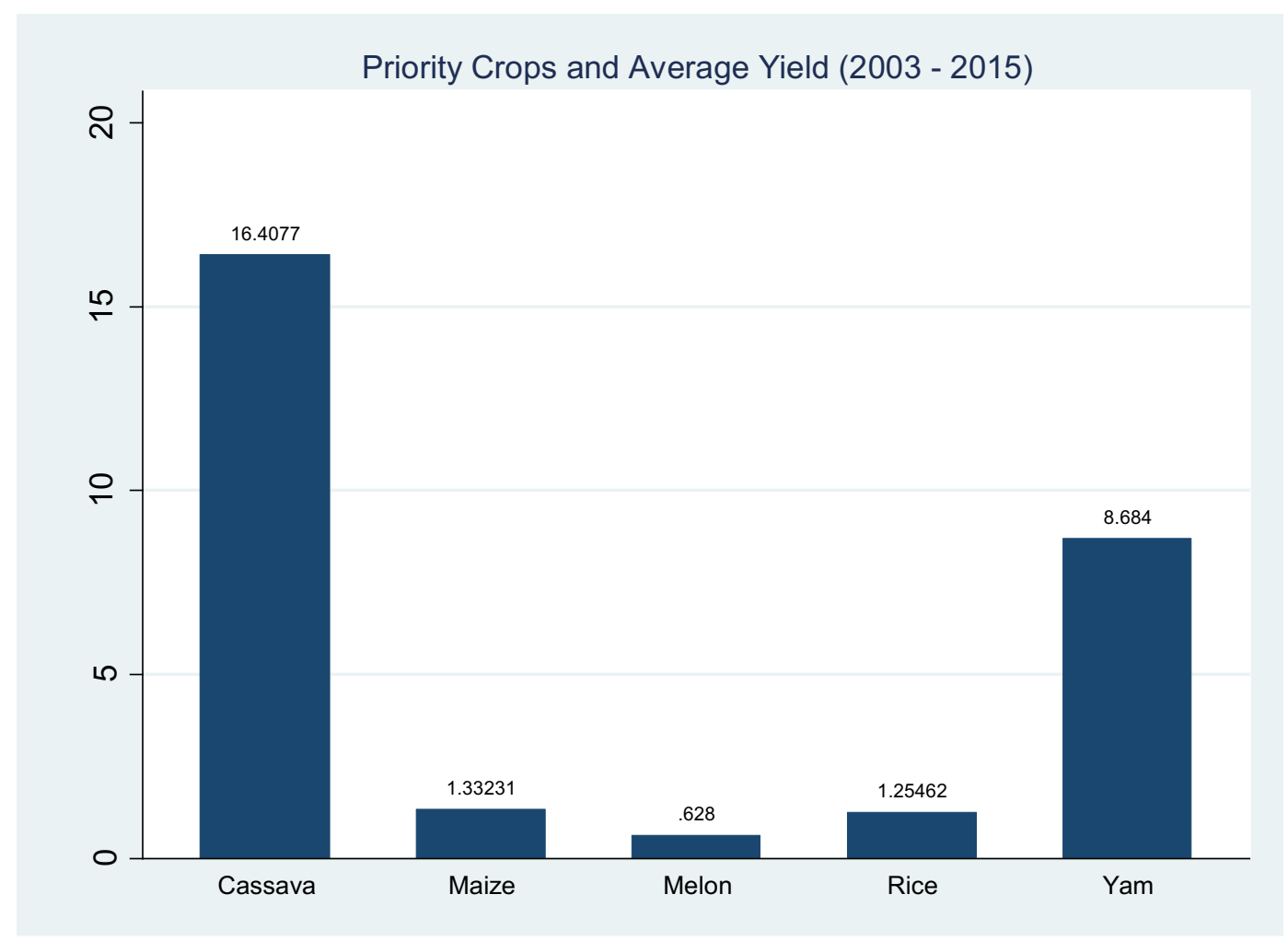

Figure A2: Yield per hectare of selected priority crops in Ogun State, Nigeria Source: The Authors'

\footnotetext{
${ }^{\mathrm{i}}$ CGIAR is a consortium of agricultural research centres, which was formerly called Consultative Group on International Agricultural Research. For details, see www.cgiar.org

${ }^{2}$ Ogun State at a Glance, Government of Ogun State Website available at http://ogunstate.gov.ng/ogun-state/ last accessed September 25, 2018.

${ }^{3}$ In this case, the intended size of land by the potential corporate applicant is negotiated with the State Government in conjunction with the LGA as well as the leaders of the community where such land is to be acquired.

${ }^{4}$ Due to the very low indices of cocoyam, potato, and cowpea, they are excluded from these descriptive analyses. ${ }^{5} \mathrm{http}: / /$ www.fao.org/3/y5548e/y5548e08.htm

${ }^{6}$ https://www.vanguardngr.com/2018/04/boosting-rural-agriculture-ogun/

${ }^{7}$ http://ogunstate.gov.ng/ministry-of-agriculture/

${ }^{8}$ https://www.tribuneonlineng.com/112615/

${ }^{9}$ https://www.britannica.com/plant/rice

${ }^{10}$ https://www.vanguardngr.com/2018/04/boosting-rural-agriculture-ogun/

${ }^{11} \mathrm{https} / /$ www.pulse.ng/lifestyle/food-travel/yams-nigeria-is-the-highest-producer-of-this-crop-thanks-to-thesestates/478clck

${ }^{12}$ For space consideration and to avoid having to many Figures, we did not present their graphs. However, they can be made available upon request. More so, cocoyam, potato, and cowpea are not part of priority crops. While other priority crops (cocoa, plantain, and oil palm) were not covered in the survey due to the fact that the survey mainly focused on annual crops.

${ }^{13}$ Data for melon and yam is from 2003 to 2012.

${ }^{14}$ As in some States like Kwara located in North-Central Nigeria, there are a number of large-scale cassava processing machines in Ogun State.

${ }^{15}$ There are also speculations that there is more to the issue of herders-farmers conflict in terms of the possibility of having religious and political undertone; however, this is outside the focus of this present study.
} 